\title{
Structural Changes in Employment Diversification in Pakistan: Assessing the Role of Sectoral Employment Elasticities in Employment Generation
}

\author{
Fouzia Yasmin $^{a}$, Nazia Nasir $^{b}$, Noreen Safdar ${ }^{c}$, Sidra Iqbal $^{d}$ \\ ${ }^{a}$ Lecturer, Department of Economics, University of Sahiwal, Pakistan \\ Email: Fouziayasmin@uosahiwal.edu.pk \\ ${ }^{\mathrm{b}}$ Research Scholar, Department of Economics, The Women University Multan, Pakistan \\ Email: Nazianasir38@gmail.com \\ c Assistant Professor, Department of Economics, The Women University Multan, Pakistan \\ Email: Noreen.safdar@wum.edu.pk \\ ${ }^{\mathrm{d}}$ Lecturer, School of Economics, Bahauddin Zakariya University, Multan, Pakistan \\ Email: sidrach@bzu.edu.pk
}

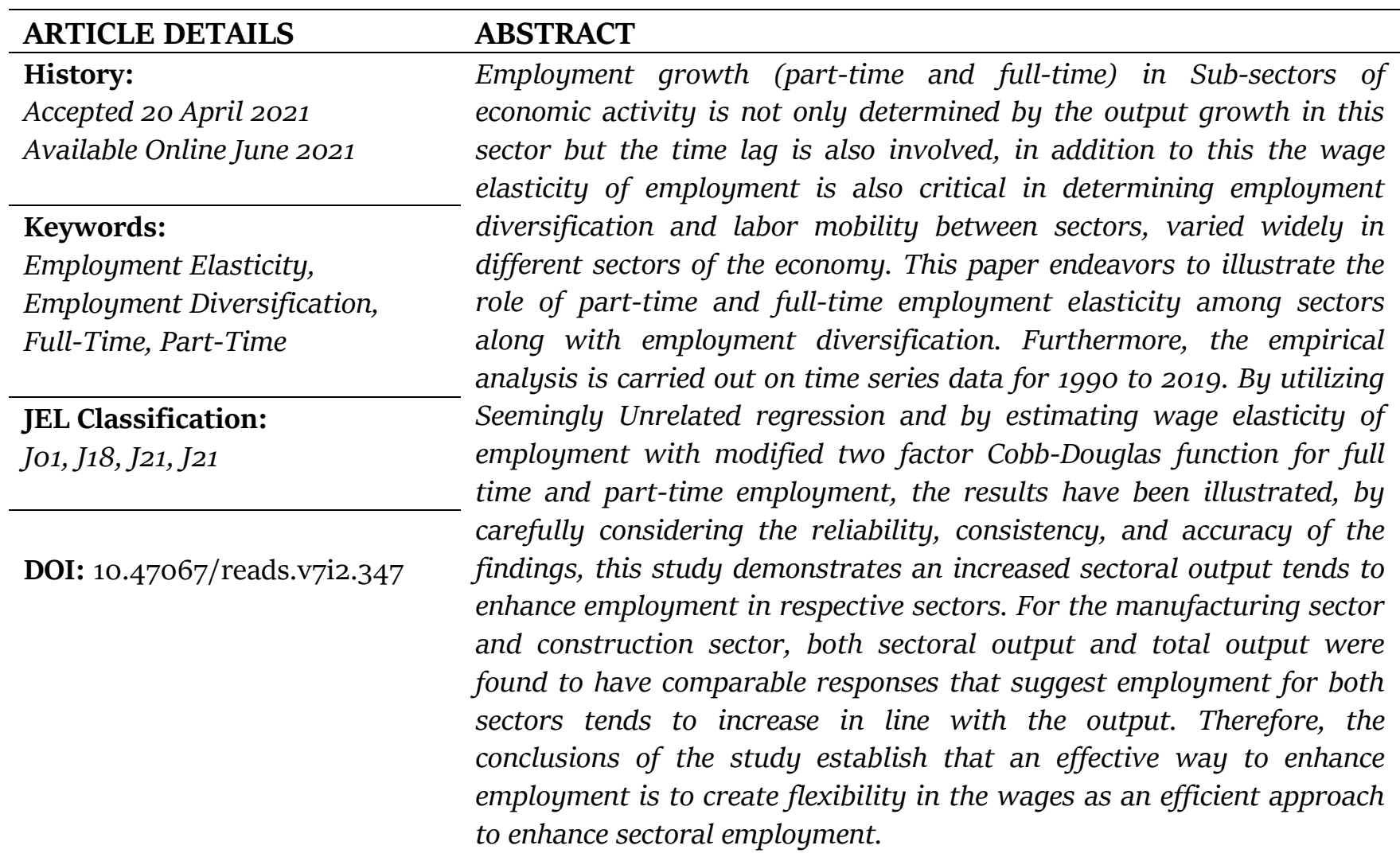

(C) 2021 The authors. Published by SPCRD Global Publishing. This is an open access article under the Creative Commons Attribution-

NonCommercial 4.0

Corresponding author's email address: Fouziayasmin@uosahiwal.edu.pk

\section{Introduction}

Pakistan has made notable progress in employment generation over decades, the share 


\section{Review of Economics and Development Studies, Vol. 7 (2) 2021, 147-161}

employed labor force was increased from 37.22 to $\mathbf{6 1 . 7 1}$ from 2000 to 2018 (Pakistan Economic Survey 2019-20), consequently, more than 30 million individuals indicated an uplift from poverty. To sustain this inclusive rise in employment, the utilization of the labor force in income-generating activities is critical for economic growth as being the most valuable and abundant asset of the country (Nasir et al., 2021). Though, many indicators elaborate underutilization of the country's human resource, with the reason that 208 million people are dependent on the earnings of 46 million wage earners only (Pakistan Labor Force Survey, 2017) as supported by the demographic structure of the population. Furthermore, many other factors are also responsible e.g., low rate of female participation, nonpaid or low-paying jobs (Shaheen, et al., 2015) Amid the present recovery stage of the economy calls for urgent policy efforts to address the absorption of the labor force in economic activity in all sub-sectors (Alimova, 2021) for both full time and part-time employment in Pakistan.

Full-time and part-time employment can differ because workers increase leisure with low real wages and decrease leisure with relatively high real wage rates (Lucas and Rapping, 1969). An elastic labor supply serves as a core component of the labor market (Kimmel \& Kniesner, 1998; Christiano \& Eichenbaum, 1992). The estimation of wage elasticities for both part-time and full-time labor. This elasticity of employment is of great policy interest since it limits the impact of policies in various subsectors in different aspects. Estimating the magnitude of employment elasticities as being a significant subject matter of empirical literature, it focuses on employing a maximum number of individuals in local labor markets (full-time and part-time) in all sectors of the economy. Furthermore, employment diversification and sectoral employment elasticities are also important as both are interrelated to each other (Evangelista \& Savona, 2003).

Figure 1 illustrated the characteristics of Pakistan's labor market in 2017, only 57 million individuals are employed out of the total population of 208 million in the country, in addition, there is only one wage earner provide the living to $\mathrm{s}$ for 3.6 people in Pakistan as approximately half of the population is not in the labor force. The country has a working-age population of 116 million with a non-working age population of 92 million, furthermore, the total labor force is 59 million, moreover, employed males are 45 million and employed females are 12 million with only 11 million unemployed labor force, in addition to these, the ratio of paid males are far more than paid females 40 and 6 million respectively.

Figure 1: An overview of Pakistan's Labor Market in 2017 (millions)

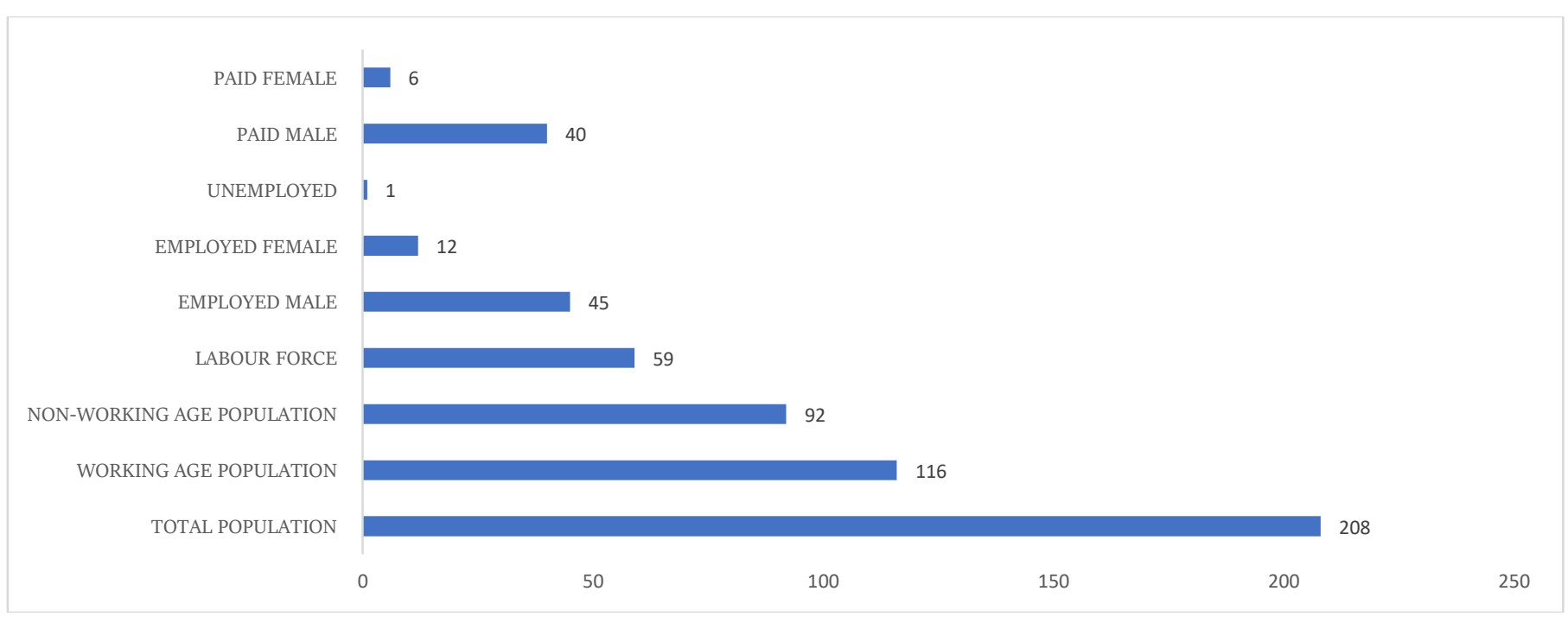

Source: Pakistan Labor Force Survey, 2017 
Figure 2: Male and Female Employment by Sector 2017 (Percentage)

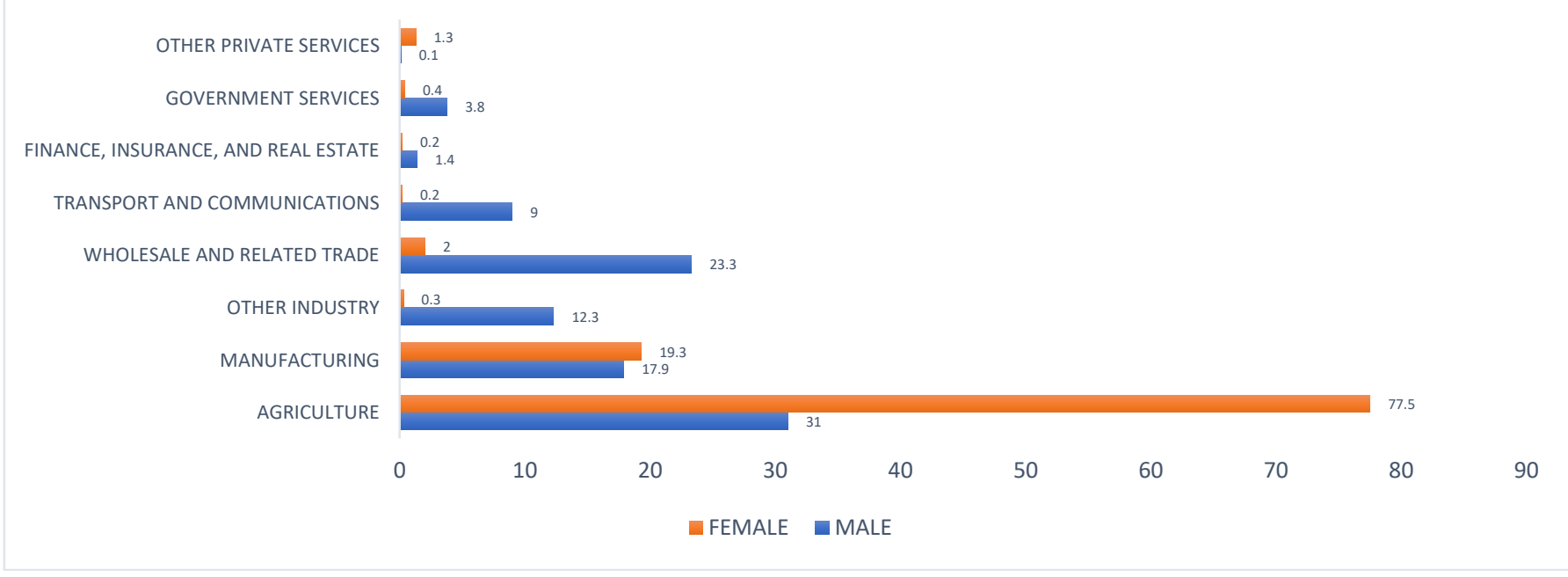

Figure 2 illustrates the ratio of male and female share in employment in percentage. Various sectors are disaggregated showing the employment percentages, for instance, agriculture the percentage contribution of males is 31 and for females, it is 77.5 percent, further, it is 17.9 and 19.3 for males and females respectively in the manufacturing sector, similarly, it is 12.3 and 0.3 for other industry, furthermore, wholesale and related trade comprise 23.3 for males and 2 percent for females, the transport and communications employ 9 percent males and 0.2 percent females, that is 1.4 and $0.2,3.8$ and $0.4,0.1$ and 1.3 for males and females in finance, insurance, and real estate and government services and other private services respectively.

\section{Literature Review}

In the neoclassical model of labor markets, real wage growth is first determined by the labor trend and employment growth in diversified environments responds to the functional relationship. The scope of the trade-off of labor mobility with employment diversification is indispensable to accommodate the labor in the working of the economy. Therefore, work-cause runs more than other means, consequently, public policy and macro-climate determine how employment growth is beneficial for the overall economy.

Jouili and khemissi (2019) estimate the impact of graduated employment on the economic diversification in Saudi Arabia and concluded that Employment diversification had a positive impact on graduated students for their job creation. Xiao et al. (2018) examined the drivers of industrial diversification, the showed about the entry of new industry that how it become more productive for the economy through breaking the past and introduced highly innovative product line. Dey (2018) explained the Role of employment diversification to reduce the poverty among the small and marginal landholders in India and showed that employment diversification towards the non-farm sector brought the small landholder into a positive path to curtail.

Borah (2018) focused on the structure of the non-farm sector of North East India and explore the range of different things that had an impact on the economic development of the economy. As the economy moved on a high-capacity innovation level, the trend of workers moved from farm to nonfarm sector and increased workforce of women due to rise in education moved them to work from primary to other sectors. Reddy (2016) examined the impact of education on employment diversification among the tribal youth showing education, employment, and expected wages of rural youth affects the employment pattern in India. The conclusion reveals that despite all education 


\section{Review of Economics and Development Studies, Vol. 7 (2) 2021, 147-161}

promoting programs most youth still depends on agriculture livelihood. Oluwasola (2015) estimates the Enhancement of employment diversification through given vegetable production in Nigeria. The Vegetable farmers are educated and skilled. The passion for work among vegetable farmers not only raised the employment level but also income sources increased. This proposed that Education, experience, and access to credit all were the important factors that derived income and employment.

Ruhat et al. (2014) Evaluated rural livelihood diversification strategies. Education, ethnicity, and location for employment diversification were explored for Nepal. To bring the work diversified labor force should be educated and the location of opportunities area must be easy to access for people. The complete conclusion stated that Education had a major factor for employment diversification as the literacy rate. Senadza (2012) discusses the effect of Non-farm employme nt diversification on the income of rural people of Ghana. The finding predicts the determinant of non-farm diversification employment pattern. Wage employment and non-farm employment positively affect income. Nelen et al. (2013) examined the part-time employment of firm productivity under the production function with the GMM method of estimation to evaluate the productivity with panel data for heterogeneous employment. The conclusion illustrated that firms have a huge share of part-time employment forecast and high productivity levels, as compared to full-time employment due to their effectiveness.

Deker (2002) elaborated the importance of two major types of atypical employment consist of part-time and temporary workers and concluded a higher probability of gender and lower probability of intermediate skills are responsible for part-time work. Arif (2012) estimated the relationship between labor reallocation and sectoral productivity in Pakistan and illustrated that economic growth depends on sectoral structure, in addition, the manufacturing sector absorbs more labor force than the workers move from the agricultural sector to the service sector. Hou (2010) examined the pattern and challenge of youth employment in Pakistan and analyzed that the youth unemployment rate is higher, the labor market had not smooth and most of the young person working without paid as family workers.

Nasir (2000) examined the earning differential between the private and public sectors that are divided into two categories formal and informal and concluded that earnings of public sectors had more than the private sector due to their personal human capital qualities. Informal private sectors suffered more due to their poor wage structure than the formal private and public sectors.

Islam \& Nazara (2000) have demonstrated that employment resilience represents a measure of the labor market's response to changes in macroeconomic conditions, and also measures the impact of economic growth on model job creation. Wage rate resilience measures the percentage change in employment when there is a percentage change in the wage rate. (Montalvo \& Ravallion, 2011) stated that employment diversification contributes to overall economic development while making it clear that overall GDP growth and growth in certain sectors, such as the agricultural sector, by the reason that many of the poor are working in the agricultural sector, therefore, the results of employment elasticity are different for regional development and overall economic growth. (Suryadarma et al., 2013) showed that economic growth increases employment opportunities in the labor market and that growth in labor market employment further promotes economic growth. Increased employment diversification helps to achieve development, as labor demand increases, workers' incomes and real wages increase, and then their living standards and purchasing power increase.

Since the late 1990s, a large number of empirical studies have indicated that the rural nonagricultural sector and income diversification have been focused on development research 


\section{Review of Economics and Development Studies, Vol. 7 (2) 2021, 147-161}

(Canagarajah et al., 2001; Ellis and Mdoe, 2003). Numerous case studies and preliminary data sets indicate that income from the non-agricultural sector is increasing (Haggblade et al., 2007). These studies assess the implications of the growing non-agricultural sector on agricultural policy and see it as a strategy for rural families to deal with natural upheavals and policy shocks. Rural families have different assets in the study of poverty and employment strategies and they specialize in the same activities or choose to earn from agricultural and non-agricultural activities. (McElwee and Bosworth, 2010).

Several case studies and primary data sets suggested that the income from the nonfarm sector is increasing. These studies evaluate the implication of the rising non-farm sector on agricultural policy and find it a strategy of the rural household to cope with natural upheavals and policy shocks. Studies on poverty and employment strategies in the rural households have different asset endowments and they either specialize in a single activity or choose to earn both from farm and nonfarm activities. Some studies examined the relationship between participation in rural nonfarm employment using individual and household characteristics such as gender, education, road access, access to electricity and water, landholding, etc (Adams and Alderman, 1992; Yang, 1997; Arif et al., 2000; Kaur, 2010; Bezu et al, 2013).

\section{Data Methodology}

The study at hand endeavors to investigate the structural changes in employment diversification and the role of wage elasticity of employment in Pakistan, in addition to this, the study investigated the impact of changes in GDP of sub-sectors in determining sectoral employment. It used annual data of 1990 t 2019 for the analysis. The data comprise of time series data for total employment in each sector, wage employment, total gross domestic product (GDP) by sectors, and lags of employment and wages that have been collected from various sources.

\section{Empirical and Theoretical Methodology}

This section converses on the cautious measures that have been taken to minimize its shortcomings of other estimation of the employment elasticity which will, later on, contributes to employment elevation and compares models (Liew, 2007). In this study, the main method use in the estimation is the Seemingly Unrelated Regression (SUR) method. SUR regression is the best estimation strategy by using this data set. Now, we proceed to the discussions concerning models that are used in this study to explain the relationship between employment elasticity and employment diversification in Pakistan. As mentioned earlier, employment elasticity is calculating the impact of wages on part-time and full-time employment.

\subsection{Theoretical Model Specification}

Key details of empirical and theoretical model specification. The proposed model is the (SUR), (Zellner, 1962). The basic form of equations with the dependent variable and various control variables. The basic formations with $k$ number of observations are as follows:

$$
Y_{k l}=X^{\prime} \partial_{l}+e_{k l}
$$

That can be explained in matrix form as follows:

$$
\left[\begin{array}{l}
Y_{1} \\
Y_{2} \\
Y_{k}
\end{array}\right]=\left[\begin{array}{ccc}
X 1 & 0 & 0 \\
0 & X 2 & 0 \\
0 & 0 & X k
\end{array}\right]\left[\begin{array}{l}
\partial_{1} \\
\partial_{2} \\
\partial_{3}
\end{array}\right]+\left[\begin{array}{l}
e_{1} \\
e_{2} \\
e_{k}
\end{array}\right]
$$


In the above model it is assumed that the error term has a zero mean and homoscedastic variance, as under:

$$
E\left(\varepsilon_{k l} \varepsilon_{k l} \mid X\right)=\sigma_{l l^{\prime}} \text { and } \sigma_{l l^{\prime}} \neq 0 \text { where } l \neq l^{\prime}
$$

In this scenario, the error term $\varepsilon_{l}$ satisfy three conditions: first, the mean is $\varepsilon_{l}$ : $E\left(\varepsilon_{l} \mid X\right)=0$; the second is the Variance is $\mathcal{E}_{l}: E\left(\mathcal{E}_{l} \mathcal{E}_{l}^{\prime} \mid \mathcal{X}\right)=\sigma_{l l} I_{M}$; third, Co-variance of $\mathcal{E}_{l \text { across }}$ equations is $l$ and $l^{\prime}: E\left(\varepsilon_{l} \varepsilon_{l^{\prime}}^{\prime} \mid X\right)=\sigma_{l l^{\prime}} I_{M}$ where $l \neq l^{\prime}$. Nevertheless, the approximation of SUR model comprises two points: In the first stage, respectively all equations under the regression system are predictable by OLS. While the second phase, the calculated value of $\widehat{\Sigma}$ is replaced into a sum of GLS estimatore, which contemplates an optimal estimator from the list of estimators. SUR model can be applied when linear equations are connected only done by their residual terms.

\subsection{Empirical Model Specification}

The practical model of employment diversification patterns includes, wage rate, the share of GDP of each sub-sector are the control variables and employment (the dependent variable of each sub-sector) has two-measurement i.e. full-time and part-time employment. This model utilized lagged wage of two times and lagged employment of one time. Full-time employment is denoted by $e_{F t}$ and part-time employment by $e_{P t}$ where the part-time and full-time wages, the share of GDP are donated by $r_{p t}, r_{f t}, \emptyset Y$ respectively.

Model 1: Employment in the Agriculture sector

Agri $e_{F t}=A g \alpha_{a a} e_{F t-1}+A g \alpha_{a b} e_{P t-1}+A g \beta_{1} r_{F t-1}+A g \beta_{2} r_{F t-2}+A g \varphi Y+\epsilon$

Agri em $\mathrm{Pt}_{\mathrm{t}}=A g \alpha_{b a} e_{P t-1}+A g \alpha_{b b} e_{F t-1}+A g \gamma_{1} r_{P t-1}+A g \gamma_{2} r_{P t-2}+A g \varphi Y+\epsilon$

Model 2: Employment in the Manufacturing sector

$M n e_{F t}=M n \alpha_{a a} e_{F t-1}+M n \alpha_{a b} e_{P t-1}+M n \beta_{1} r_{F T-1}+M n \beta_{2} r_{F t-2}+M n \varphi Y+\mu$

$M n e_{P t}=M n \alpha_{b a} e_{P t-1}+M n \alpha_{b b} e_{F t-1}+M n \gamma_{1} w_{P t-1}+M n \gamma_{2} r_{P t-2}+M n \varphi Y+\mu$

Model 3: Employment in Construction Sector

Cn $e_{F t}=C n \alpha_{a a} e_{F t-1}+C n \alpha_{a b} e_{P t-1}+C n \beta_{1} r_{F t-1}+C n \beta_{2} r_{F t-2}+C n \varphi Y+\sigma$

$C n e_{P t}=C n \alpha_{b a} e_{P t-1}+C n \alpha_{b b} e_{F t-1}+C n \gamma_{1} r_{P t-1}+C n \gamma_{2} r_{P t-2}+C n \varphi Y+\sigma$

Model 4: Employment in Wholesale and Retail Trade Sector

$W R e_{F t}=W R \alpha_{a a} e_{F t-1}+W R \alpha_{a b} e_{P t-1}+W R \beta_{1} r_{F t-1}+W R \beta_{2} r_{F t-2}+W R \varphi Y+\rho$

$W R e_{P t}=W R \alpha_{b a} e_{P t-1}+W R \alpha_{b b} e_{F t-1}+W R \gamma_{1} r_{P t-1}+W R \gamma_{2} r_{P t-2}+W R \varphi Y+\rho$

Model 5: Employment in Electricity and Gas Distribution Sector

$E G e_{F t}=E G \alpha_{a a} e_{F t-1}+E G \alpha_{a b} e_{P t-1}+E G \beta_{1} r_{F t-1}+E G \beta_{2} r_{F t-2}+E g \varphi Y+\vartheta$

$E G e_{P t}=E G \alpha_{b a} e_{P t-1}+E G \alpha_{b b} e_{F t-1}+E G \gamma_{1} r_{P t-1}+E G \gamma_{2} r_{P t-2}+E g \varphi Y+\vartheta$

Model 6: Employment in Transport, storage and communication Sector

$\operatorname{Tr} e_{F t}=\operatorname{Tr} \alpha_{a a} e_{F t-1}+\operatorname{Tr} \alpha_{a b} e_{P t-1}+\operatorname{Tr} \beta_{1} r_{F t-1}+\operatorname{Tr} \beta_{2} r_{F t-2}+\operatorname{Tr} \varphi Y+\tau$

$\operatorname{Tr} e_{P t}=\operatorname{Tr} \alpha_{a b} e_{P t-1}+\operatorname{Tr} \alpha_{b b} e_{F t-1}+\operatorname{Tr} \gamma_{1} r_{P t-1}+\operatorname{Tr} \gamma_{2} r_{P t-2}+\operatorname{Tr} \varphi Y+\tau$ 
Review of Economics and Development Studies, Vol. 7 (2) 2021, 147-161

Table 1: Descriptive Analysis of the data by Sectors

\begin{tabular}{|c|c|c|c|c|c|c|c|c|c|c|c|c|}
\hline & \multicolumn{2}{|c|}{ Agriculture } & \multicolumn{2}{|c|}{$\begin{array}{l}\text { Electricity and Gas } \\
\text { Distribution }\end{array}$} & \multicolumn{2}{|c|}{ Manufacturing } & \multicolumn{2}{|c|}{ Construction } & \multicolumn{2}{|c|}{$\begin{array}{l}\text { Wholesale and } \\
\text { Retail Trade }\end{array}$} & \multicolumn{2}{|c|}{$\begin{array}{l}\text { Transport, } \\
\text { storage and } \\
\text { communication }\end{array}$} \\
\hline & Min & Max & Min & Max & Min & Max & Min & Max & Min & Max & Min & Max \\
\hline Growth Rate & -5.29 & 11.72 & 1.5 & 4.1 & 13 & 18.9 & 2 & 4.2 & 15.2 & 18.9 & $9 \cdot 5$ & 13.4 \\
\hline $\begin{array}{l}\text { Share In } \\
\text { Growt }\end{array}$ & 18.5 & 26.1 & -26.6 & 59 & -4.2 & $15 \cdot 5$ & -11.2 & $24 \cdot 3$ & -2.4 & 12 & .84 & 10.46 \\
\hline $\begin{array}{l}\text { Part-time } \\
\text { Wages }\end{array}$ & 151.68 & $\begin{array}{l}2375 \cdot 7 \\
6\end{array}$ & 2.52 & 20.28 & 45.84 & 591.12 & 9.72 & 184.44 & 2.04 & 143.64 & .21 & 3.01 \\
\hline $\begin{array}{l}\text { Part-time } \\
\text { Employment }\end{array}$ & $4 \cdot 36$ & 5.49 & .01 & .35 & 31398.72 & 206773.4 & 10438.68 & 196824 & 28092 & 183985.2 & 40650.72 & 231600 \\
\hline $\begin{array}{ll}\text { Full Time } \\
\text { Wages }\end{array}$ & 10438.68 & 115740 & 55201.08 & 370464 & .4 & .83 & .24 & .52 & .02 & .51 & .01 & .17 \\
\hline $\begin{array}{l}\text { Full Time } \\
\text { Employment }\end{array}$ & 8.1 & 11.86 & .23 & .63 & $4 \cdot 3$ & $5 \cdot 33$ & 2.69 & 3.86 & 2.34 & 3.29 & .17 & 1.87 \\
\hline $\begin{array}{l}\text { Total } \\
\text { Employment }\end{array}$ & 38.5 & 50.04 & .43 & .87 & 10.12 & 17.21 & $5 \cdot 38$ & 8.12 & $5 \cdot 42$ & 7.90 & 4.89 & 6.22 \\
\hline
\end{tabular}

Source: Estimation by the author using STATA 14.1 


\section{Empirical analysis}

Empirical analysis consists of two stages, first the elasticity estimates using two factor CobbDouglas function and the estimation of the parameters by using the Seemingly Unrelated Regression.

\subsection{Employment elasticity Analysis of wages by Sectors of Full time and part-time employment}

Employment elasticity of wages is the measurement of responsiveness of employment to the changes of the wage rate. This study examines the elasticities at the level of each sector individually for both part-time and full-time employment. Several approaches were employed to quantify the employment elasticity of wages, such as the Cobb-Douglas method of measuring elasticity. This study utilizes data from 1990 to 2019 involving annual time series data. Still there exists limitations in involving model and data, therefore the study used careful measures to confirm that these inadequacies of the previous methodologies have been taken into account that ensures the consistency, reliability, and accuracy of the findings. A most simple approach to investigate the wage elasticity of marginal is to quantify the response and sensitivity of employment to change in the wage rate. This can be accomplished by conniving the simple wage-employment elasticity, as the percentage change in employment (E) due to percentage change in Wages (W), this can be expressed as follows:

$$
\varepsilon=\left(\frac{d E}{d W}\right)\left(\frac{W}{E}\right)
$$

This can be interpreted as changes in the percentage of employment when there is a one percent increase in the wage rate. However, this elasticity measure the elasticity of full-time and part-time employment to the change in wages cetris peribus (Islam \& Nazara, 2000). It is an estimation technique that uses Ordinary Least Square (OLS) regression, which produces reliable and stable statistics in the measurement of employment elasticity. By using a double-log linear form of the model follows the form as under:

$$
E_{i}=A W_{i}^{a} u_{t}
$$

And the double log-linear model, the coefficient measure the wage elasticity of employment $\varepsilon$ expressed as follows:

$$
\ln E=A+\operatorname{aln} W+u_{t}
$$

Variable $E$ and $W$ are employment and wages respectively with $u_{t}$, the residual term of the model and the subscript $i$ denote the sectors. This equation indicates that sectoral employment is determined by wage rate. 
Review of Economics and Development Studies, Vol. 7 (2) 2021, 147-161

Table 2: Wage elasticity of Employment Analysis by Sectors and by employment type (Full time and part-time)

\begin{tabular}{|c|c|c|c|c|}
\hline & \multicolumn{2}{|c|}{ Part-time } & \multicolumn{2}{|c|}{ Full-time } \\
\hline & Own price & Cross price & Own price & Cross price \\
\hline Agricultural & $-0.1964(0.000)$ & $0.2699(0.000)$ & $0.4807(0.000)$ & $-0.4450(0.000)$ \\
\hline Manufacturing & $0.1495(0.016)$ & $-0.1164(0.000)$ & $0.1762(0.000)$ & $-0.0789(0.006)$ \\
\hline Electricity and Gas & $0.4318(0.170)$ & $-0.3894(0.000)$ & $-0.0433(0.000)$ & $-0.2448(0.000)$ \\
\hline Construction & $-0.0759(0.167)$ & $-0.07333(0.000)$ & $0.1195(0.000)$ & $-0.0324(0.197)$ \\
\hline Wholesale and retail trade & $-0.2617(0.077)$ & $-0.0455(0.333)$ & $0.1038(0.000)$ & $-0.0140(0.374)$ \\
\hline Transport & $0.0322(0.8329)$ & $-0.2252(0.0000)$ & $-0.0012(0.9245)$ & $-.2387(0.0002)$ \\
\hline
\end{tabular}

Source: Estimation by the author using STATA 14.1

Note: Values in the Parenthesis indicate P-value. 
Table 2 illustrates the Wage elasticity of Employment Analysis by Sectors and by employment type for full-time and part-time. A negative value of wage employment elasticity indicates a negative impact of a rise in wages on employment, while, a positive value of wage employment elasticity indicates a positive impact of a rise in wages on the respective employment type. Furthermore, own wage elasticity illustrates the impact of change in full-time wages on full-time employment, whereas, the cross-price elasticity explains the impact of change in full-time wages on part-time employment vice era. Own and cross wage elasticity for 6 sub-sectors (Agriculture, Manufacturing, Electricity and Gas, Construction, Wholesale and retail trade, Transport) has been illustrated in table 2.

\subsection{Seemingly Unrelated Regression Analysis}

As stated above, the investigation not only describes the elasticity estimates of pat time and full time to change in wages, nonetheless, it also suggests a description of the sectoral employment responsiveness to changes in the sectoral wage rate. Consequently, an equation from Islam and Nazara (2000) stated that economic development helps in providing adequate employment. For countries with abundant labor, rapid economic growth is still needed to focus on improving labor productivity and providing more employment opportunities. 
Review of Economics and Development Studies, Vol. 7 (2) 2021, 147-161

Table 3: Empirical Estimates using SUR of Full Time Employment Diversification

\begin{tabular}{|c|c|c|c|c|c|c|}
\hline Variables & Agriculture & Construction & Electricity & Manufacturing & $\begin{array}{l}\text { Wholesale } \\
\text { And Retail } \\
\text { Trade }\end{array}$ & $\begin{array}{l}\text { Transport, } \\
\text { Storage, And } \\
\text { Communication }\end{array}$ \\
\hline & $\begin{array}{l}\text { Coefficients } \\
\text { (P-Value) }\end{array}$ & $\begin{array}{l}\text { Coefficients } \\
\text { (P-Value) }\end{array}$ & $\begin{array}{l}\text { Coefficients } \\
\text { (P-Value) }\end{array}$ & $\begin{array}{l}\text { Coefficients } \\
\text { (P-Value) }\end{array}$ & $\begin{array}{l}\text { Coefficients } \\
\text { (P-Value) }\end{array}$ & $\begin{array}{l}\text { Coefficients } \\
\text { (P-Value) }\end{array}$ \\
\hline Full Time Wage (-1) & $\begin{array}{l}0.000 \\
(0.51) \\
\end{array}$ & $\begin{array}{l}0.0030 \\
(0.02)\end{array}$ & $\begin{array}{l}-0.073 \\
(0.03) \\
\end{array}$ & $\begin{array}{l}0.256 \\
(0.07)\end{array}$ & $\begin{array}{l}0.549 \\
(0.00)\end{array}$ & $\begin{array}{l}0.331 \\
(0.01) \\
\end{array}$ \\
\hline Full Time Wage (-2) & $\begin{array}{l}-0.000 \\
(0.35)\end{array}$ & $\begin{array}{l}0.572 \\
(0.00)\end{array}$ & $\begin{array}{l}-0.048 \\
(0.26)\end{array}$ & $\begin{array}{l}-0.000 \\
(0.00)\end{array}$ & $\begin{array}{l}-1.52 \mathrm{E}-06 \\
(0.6)\end{array}$ & $\begin{array}{l}0.819 \\
(0.04)\end{array}$ \\
\hline Part-time Wage (-1) & $\begin{array}{l}-0.053 \\
(0.8)\end{array}$ & $\begin{array}{l}-0.483 \\
(0.2)\end{array}$ & $\begin{array}{l}-0.937 \\
(0.06)\end{array}$ & $\begin{array}{l}-0.000 \\
(0.00)\end{array}$ & $\begin{array}{l}3.57 \mathrm{E}-06 \\
(0.2)\end{array}$ & $\begin{array}{l}2.37 \mathrm{E}-06 \\
(0.2)\end{array}$ \\
\hline Part-time Wage (-2) & $\begin{array}{l}1.290 \\
(0.00)\end{array}$ & $\begin{array}{l}0.491 \\
(0.00)\end{array}$ & $\begin{array}{l}0.047 \\
(0.03)\end{array}$ & $\begin{array}{l}-0.003 \\
(0.00)\end{array}$ & $\begin{array}{l}0.003 \\
(0.01)\end{array}$ & $\begin{array}{l}5 \cdot 327 \\
(0.003)\end{array}$ \\
\hline $\begin{array}{l}\text { Full Time Employment } \\
(-1)\end{array}$ & $\begin{array}{l}-0.278 \\
(0.00)\end{array}$ & $\begin{array}{l}-0.000 \\
(0.09)\end{array}$ & $\begin{array}{l}0.005 \\
(0.06)\end{array}$ & $\begin{array}{l}0.001 \\
(0.06)\end{array}$ & $\begin{array}{l}0.608 \\
(0.00)\end{array}$ & $\begin{array}{l}0.002 \\
(0.03)\end{array}$ \\
\hline $\begin{array}{l}\text { Part-time Employment } \\
(-1)\end{array}$ & $\begin{array}{l}0.575 \\
(0.00)\end{array}$ & $\begin{array}{l}0.346 \\
(0.01)\end{array}$ & $\begin{array}{l}-0.307 \\
(0.06)\end{array}$ & $\begin{array}{l}0.509 \\
(0.2) \\
\end{array}$ & $\begin{array}{l}-0.296 \\
(0.000)\end{array}$ & $\begin{array}{l}5 \cdot 327 \\
(0.03)\end{array}$ \\
\hline Growth Rate & $\begin{array}{l}-0.009 \\
(0.7)\end{array}$ & $\begin{array}{l}0.005 \\
(0.14) \\
\end{array}$ & $\begin{array}{l}0.001 \\
(0.003)\end{array}$ & $\begin{array}{l}0.009 \\
(0.2)\end{array}$ & $\begin{array}{l}0.0156 \\
(0.05) \\
\end{array}$ & $\begin{array}{l}-0.019 \\
(0.4) \\
\end{array}$ \\
\hline C & $\begin{array}{l}4.427 \\
(0.03)\end{array}$ & $\begin{array}{l}2.024 \\
(0.000)\end{array}$ & $\begin{array}{l}0.471 \\
(0.000)\end{array}$ & $\begin{array}{l}3.213 \\
\text { (0.000) }\end{array}$ & $\begin{array}{l}1.301 \\
(0.000)\end{array}$ & $\begin{array}{l}0.607 \\
(0.025)\end{array}$ \\
\hline
\end{tabular}

Source: Estimation by the author using STATA 14.1.

Note: Values in the Parenthesis indicate P-value. 
Table 4: Empirical Estimates Using SUR of Part-Time Employment Diversification

\begin{tabular}{|c|c|c|c|c|c|c|}
\hline Variables & Agriculture & Construction & Electricity & Manufacturing & $\begin{array}{l}\text { Wholesale And } \\
\text { Retail Trade }\end{array}$ & $\begin{array}{l}\text { Transport, } \\
\text { Storage, And } \\
\text { Communication }\end{array}$ \\
\hline & $\begin{array}{l}\text { Coefficients } \\
\text { (P-Value) }\end{array}$ & $\begin{array}{l}\text { Coefficients } \\
\text { (P-Value) }\end{array}$ & $\begin{array}{l}\text { Coefficients } \\
\text { (P-Value) }\end{array}$ & $\begin{array}{l}\text { Coefficients } \\
\text { (P-Value) }\end{array}$ & $\begin{array}{l}\text { Coefficients } \\
\text { (P-Value) }\end{array}$ & $\begin{array}{l}\text { Coefficients } \\
\text { (P-Value) }\end{array}$ \\
\hline Full Time Wage (-1) & $\begin{array}{l}-0.000 \\
(0.000)\end{array}$ & $\begin{array}{l}4.385 \\
(0.008)\end{array}$ & $\begin{array}{l}0.300 \\
(0.02)\end{array}$ & $\begin{array}{l}-3.32 \mathrm{E}-06 \\
(0.01)\end{array}$ & $\begin{array}{l}0.172 \\
(0.00)\end{array}$ & $\begin{array}{l}0.001 \\
(0.9) \\
\end{array}$ \\
\hline Full Time Wage (-2) & $\begin{array}{l}-0.000 \\
(0.000)\end{array}$ & $\begin{array}{l}0.676 \\
(0.01)\end{array}$ & $\begin{array}{l}-0.051 \\
(0.01)\end{array}$ & $\begin{array}{l}-5 \cdot 37 \mathrm{E}-06 \\
(0.00)\end{array}$ & $\begin{array}{l}5 \cdot 34 \mathrm{E}-\mathrm{o} 7 \\
(0.6)\end{array}$ & $\begin{array}{l}-3.00 E-07 \\
(0.07)\end{array}$ \\
\hline Part-time Wage (-1) & $\begin{array}{l}0.016 \\
(0.100)\end{array}$ & $\begin{array}{l}0.238 \\
(0.06)\end{array}$ & $\begin{array}{l}2.138 \\
(0.00) \\
\end{array}$ & $\begin{array}{l}-0.000 \\
(0.004)\end{array}$ & $\begin{array}{l}-3.55^{\mathrm{E}-06} \\
(0.007)\end{array}$ & $\begin{array}{l}0.001 \\
(0.3)\end{array}$ \\
\hline Part-time Wage (-2) & $\begin{array}{l}-0.000 \\
(0.000)\end{array}$ & $\begin{array}{l}-2.15 \mathrm{E}-\mathrm{O} 7 \\
(0.08) \\
\end{array}$ & $\begin{array}{l}0.078 \\
(0.07) \\
\end{array}$ & $\begin{array}{l}0.001 \\
(0.00)\end{array}$ & $\begin{array}{l}-0.001 \\
(0.02) \\
\end{array}$ & $\begin{array}{l}0.55^{2} \\
(0.00)\end{array}$ \\
\hline FullTime Employment (-1) & $\begin{array}{l}1.57 \mathrm{E}-06 \\
(0.7)\end{array}$ & $\begin{array}{l}1.36 \mathrm{E}-\mathrm{o6} \\
(0.2)\end{array}$ & $\begin{array}{l}-0.000 \\
(0.4)\end{array}$ & $\begin{array}{l}0.000 \\
(0.003)\end{array}$ & $\begin{array}{l}-0.000 \\
(0.14)\end{array}$ & $\begin{array}{l}0.589 \\
(0.00)\end{array}$ \\
\hline Part-time Employment (-1) & $\begin{array}{l}0.006 \\
(0.008)\end{array}$ & $\begin{array}{l}-0.0825 \\
(0.03)\end{array}$ & $\begin{array}{l}0.005 \\
(0.6)\end{array}$ & $\begin{array}{l}-0.000 \\
(0.09)\end{array}$ & $\begin{array}{l}0.082 \\
(0.00)\end{array}$ & $\begin{array}{l}3.792 \\
(0.03)\end{array}$ \\
\hline Growth Rate & $\begin{array}{l}-0.011 \\
(0.002)\end{array}$ & $\begin{array}{l}0.001 \\
(0.09)\end{array}$ & $\begin{array}{l}-0.000 \\
(0.6)\end{array}$ & $\begin{array}{l}0.000 \\
(0.005)\end{array}$ & $\begin{array}{l}-0.000 \\
(0.9)\end{array}$ & $\begin{array}{l}-0.000 \\
(0.83)\end{array}$ \\
\hline C & $\begin{array}{l}4.17 \\
(0.000)\end{array}$ & $\begin{array}{l}0.508 \\
(0.000)\end{array}$ & $\begin{array}{l}0.421 \\
(0.164)\end{array}$ & $\begin{array}{l}-0.030 \\
(0.8)\end{array}$ & $\begin{array}{l}-0.025 \\
(0.8)\end{array}$ & $\begin{array}{l}0.0486 \\
(0.03)\end{array}$ \\
\hline
\end{tabular}

Source: Estimation by the author using STATA 14.1

Note: Values in the Pranthesis indicates P-value. 


\section{Review of Economics and Development Studies, Vol. 7 (2) 2021, 147-161}

Table estimated the parameters by using SUR model, represents the estimated values of parttime and full-time employment of six sub-sectors i.e. agricultural, construction and electricity, manufacturing, wholesale, and transport sectors. For full-time estimates of the first three sectors, the coefficients of growth rate are positive for electricity while agriculture and construction have illustrated an insignificant impact on employment. One unit change in the 1st lag of agriculture and construction sectors has a positive impact on sectoral employment exhibiting a rise in full-time employment in the electricity sector (Ali, 2005). In the construction sector lag of part-time wages having a positive and significant impact on part-time construction employment (sheikh et al.,1992). In manufacturing, wholesale, and transport, full-time estimations of one lag of manufacturing, wholesale, and transport have a positive impact on sectoral employment. Transport sector lag of wages has a positive impact on sectoral employment (Card and Krueger, (1992).

\section{Conclusion and Policy Recommendations}

Since sustainable employment creation is one way to adjust the workforce and to gain the fruits of high economic activity, furthermore, it helps to design and implement policies and strategies for employment creation and employment creation circumstances in these sub-sectors. In addition to this, it contributes to the goal of achieving high economic growth. Therefore, special consideration is required to be paid to the emerging sectors from a variety of crises. Employment growth (part-time and full-time) in Sub-sectors of economic activity is not only determined by the output growth in this sector but the time lag is also involved in employment generation as concluded in the analysis. In addition to this wage elasticity of employment is also critical in determining employment diversification and labor mobility between sectors varied widely in different sectors of the economy. Consequently, the recommendation is advised as sector-based GDP may be enhanced to generate employment and for inclusive and sustainable economic growth with employment diversification of part-time and full-time employment.

\section{References}

Alimova, G. A. (2021). Employment, Unemployment and Poverty Reduction. The American Journal of Interdisciplinary Innovations and Research, 3(04), 84-89.

Ali-Yrkkö, J. (2005). Impact of public R\&D financing on employment (No. 980). ETLA Discussion Papers.

Arif, B. W. (2012). The nexus between labor reallocation and sectoral productivities in Pakistan: 1980 to 2007. International Journal of Peace and Development Studies, 3(5), 85-91.

Bora, D. (2020). DETERMINANTS OF LIVELIHOOD DIVERSIFICATION AMONG RABHA TRIBES OF ASSAM: A CASE STUDY. PalArch's Journal of Archaeology of Egypt/Egyptology, 17(7), 4058-4069.

Canagarajah, S., Newman, C., \& Bhattamishra, R. (2001). Non-farm income, gender, and inequality: evidence from rural Ghana and Uganda. Food policy, 26(4), 405-420.

Card, D., \& Krueger, A. B. (1992). Does school quality matter? Returns to education and the characteristics of public schools in the United States. Journal of political Economy, 100(1), $1-40$.

Christiano, L. J., \& Eichenbaum, M. (1992). Current real-business-cycle theories and aggregate labor-market fluctuations. The American Economic Review, 430-450.

Dekker, R., De Grip, A., \& Heijke, H. (2002). The effects of training and overeducation on career mobility in a segmented labour market. International Journal of Manpower.

Dey, S. (2018). The role of employment diversification in reducing vulnerability to poverty among marginal and small-holder agricultural households in India. Margin: The Journal of Applied 


\section{Review of Economics and Development Studies, Vol. 7 (2) 2021, 147-161}

Economic Research, 12(1), 88-112.

Ellis, F., \& Mdoe, N. (2003). Livelihoods and rural poverty reduction in Tanzania. World development, 31(8), 1367-1384.

Evangelista, R., \& Savona, M. (2003). Innovation, employment and skills in services. Firm and sectoral evidence. Structural Change and Economic Dynamics, 14(4), 449-474.

Haggblade, S., Hazell, P. B., \& Reardon, T. (Eds.). (2007). Transforming the rural nonfarm economy: Opportunities and threats in the developing world. Intl Food Policy Res Inst.

Hou, X. (2010). Challenges for youth employment in Pakistan: are they youth-specific?. The Pakistan Development Review, 193-212.

Islam, I., \& Nazara, S. (2000). Estimating Employment Elasticity for the Indonesian Economy. Jakarta, Indonesia: International Labour Office.

Jiun, C. Y., \& Nga, J. L. (2011). Economic growth, employment elasticity and poverty: A case of Malaysia. Prosiding Persidangan Kebangsaan Ekonomi Malaysia Ke VI, 469.

Jouili, T. A., \& Khemissi, F. M. (2019). Impact of economic diversification on graduates' employment. International Journal of Advanced and Applied Sciences, 6(3), 35-39.

Kimmel, J., \& Kniesner, T. J. (1998). New evidence on labor supply:: Employment versus hours elasticities by sex and marital status. Journal of Monetary Economics, 42(2), 289-301.

Künn-Nelen, A., De Grip, A., \& Fouarge, D. (2013). Is part-time employment beneficial for firm productivity?. ILR Review, 66(5), 1172-1191.

Liew, H. P. (2017). Health and well-being of middle age Indonesians: An application of seemingly unrelated regression (SUR) models. Health Policy and Technology, 6(3), 322-327.

Lucas Jr, R. E., \& Rapping, L. A. (1969). Real wages, employment, and inflation. Journal of political economy, 77(5), 721-754.

McElwee, G., \& Bosworth, G. (2010). Exploring the strategic skills of farmers across a typology of farm diversification approaches. Journal of farm management, 13(12), 819-838.

Montalvo, J. G., \& Ravallion, M. (2009). The pattern of growth and poverty reduction in China. The World Bank.

Nasir, N., Yasmin, F., \& Safdar, N. (2021). Employment Diversification Patterns in Pakistan: Empirical Assessment Revisited. Review of Economics and Development Studies, 7(1), 7790.

Nasir, Z. M. (2000). Earnings differential between public and private sectors in Pakistan. The Pakistan Development Review, 111-130.

Oluwasola, O. (2015). Vegetable production, livelihood diversification and employment generation in Oyo State, Nigeria. Journal of Agricultural Science, 7(8), 165.

Rahut, D. B., Ali, A., Kassie, M., Marenya, P. P., \& Basnet, C. (2014). Rural livelihood diversification strategies in Nepal. Poverty \& Public Policy, 6(3), 259-281.

Ravallion, M. (2011). A comparative perspective on poverty reduction in Brazil, China, and India. The World Bank Research Observer, 26(1), 71-104.

Reddy, P. A. (2016). Impact of Education on Employment Diversification among Tribal youth (Doctoral dissertation).

Senadza, B. (2012). Non-farm income diversification in rural Ghana: Patterns and determinants. African Development Review, 24(3), 233-244.

Shaheen, R., Shabir, G., Faridi, M. Z., \& Yasmin, F. (2015). Determinants of female employment status in Pakistan: A case of Sahiwal District. Pakistan Journal of Commerce and Social Sciences (PJCSS), 9(2), 418-437.

Sheikh, K. H., Iqbal, Z., \& Akhtar, M. R. (1992). Short-Term Employment Functions in Manufacturing Industries: An Empirical Analysis for Pakistan [with Comments]. The Pakistan Development Review, 31(4), 1267-1277. 
Suryadarma, D., Suryahadi, A., \& Sumarto, S. (2013). Sectoral growth and job creation: Evidence from Indonesia. Journal of International Development, 25(4), 549-561.

Xiao, J., Boschma, R., \& Andersson, M. (2018). Industrial diversification in Europe: The differentiated role of relatedness. Economic Geography, 94(5), 514-549. 